\section{Reconstructing the AIDS epidemic among injection drug users in Brazil}

\author{
Reconstruindo a epidemia de AIDS entre \\ usuários de drogas injetáveis brasileiros
}

\author{
Mariana A. Hacker 1 \\ Iuri C. Leite 2 \\ Adrian Renton 3 \\ Tania Guillén de Torres 4 \\ Renata Gracie 1 \\ Francisco I. Bastos 1
}

\footnotetext{
1 Centro de Informação Científica e Tecnológica, Fundação Oswaldo Cruz, Rio de Janeiro, Brasil.

2 Escola Nacional de Saúde Pública Sergio Arouca, Fundação Oswaldo Cruz, Rio de Janeiro, Brasil. 3 Unit for International Health and Development, Imperial College, London, United Kingdom.

4 Faculdade de Medicina, Universidade Federal do Rio de Janeiro, Rio de Janeiro, Brasil.

\section{Correspondence} M. A. Hacker Centro de Informação Científica e Tecnológica, Fundação Oswaldo Cruz. Av. Brasil 4365, Biblioteca de Manguinhos, Rio de Janeiro, $R J$ 21045-900, Brasil. mariana@cict.fiocruz.br
}

\section{Abstract}

The HIVIAIDS epidemic among injection drug users (IDUs) in Brazil has been unique in terms of temporal and geographical contrasts. This analysis explores these contrasts through the use of multilevel modeling. Standardized AIDS incidence rates among IDUs for Brazilian municipalities (19862000) were used as the dependent variable, with a set of social indicators as independent variables (covariates). In some States of the North/Northeast. the epidemic among IDUs has been incipient. The São Paulo epidemic extended to reach a network of municipalities, most of which located far from the capital. More recently, on a smaller scale, a similar extension has been observed in the southernmost States of the country. Both "number of physicians per inhabitant" and "standard distance to the State capital" were found to be associated with AIDS incidence. AIDS cases among IDUs appeared to cluster in wealthier, more developed municipalities. The relative weight of such extensive dissemination in key, heavily populated States prevails in the Brazilian IDU epidemic, defining a central-western-southeastern strip of wealthier middle-sized municipalities and more recently a southern strip of municipalities deeply affected by the epidemic in this population.

Intravenous Substance Abuse; Acquired Immunodeficiency Syndrome; Residence Characteristics; Incidence

\section{Introduction}

Currently in its third decade, the HIV/AIDS pandemic has progressed unabated in many different regions of the world 1 . The contrasts between relatively spared and deeply affected regions and communities have been widening, both in terms of epidemic size and trajectory and the scale and availability of preventive and treatment interventions 1 .

These contrasts have been particularly marked among injection drug users (IDUs). Stigmatized and criminalized in almost all countries, IDUs have been affected by extremely rapid epidemics in places as diverse as Bangkok, Thailand 2, Ho Chi Minh City, Vietnam 3, southern provinces of China 4 , and in different settings in Eastern Europe 5,6. On the other hand, epidemics among IDUs have been prevented in some contexts 7 and reversed in some others, such as New York in recent years 8 .

Proximate risk factors for IDUs-associated transmission such as injecting practices are determined largely by the influence of broader social, cultural, political, and legal dimensions on individual behavior 9,10. Location-specific drug use patterns and their interaction with drug availability, purity, methods of production, and trafficking routes 10,11 are particularly important.

HIV infection rates among IDUs consequently show considerable geographic varia- 
tion across and within countries, reflecting variation in the risk environment as well as the timing and extent of implementation of comprehensive prevention strategies 7 . Most programs and projects aiming to reduce drug-related harm still face political opposition and experience serious operational difficulties in many communities and countries 12 . More recently, with the introduction of highly active antiretroviral therapy (HAART) in developed countries (and a small number of developing countries), striking differences have been observed in the rates of progression of HIV infection within IDUs populations and between IDUs and other populations, due to differences in the spectrum of HIV-related illnesses, prevalence of different co-infections, access to health care, and adherence to HAART 13,14.

Owing to its size and economic and social heterogeneity, Brazil's HIV/AIDS epidemics among IDUs have been highly variable in size and trajectory in different regions, States, and municipalities 15,16.

In this paper we seek to describe the geographic variation in the size and trajectories of the AIDS epidemics in Brazil and to investigate the role of structural determinants in explaining these variations using routinely collected data broken down to the level of municipalities. These data describe: (a) numbers of new AIDS cases among IDUs in different years between 1986 and 2000 and (b) measures of socioeconomic and structural environment (SSE) areas. We have used a multilevel modeling strategy which incorporates temporal information available at the municipal and State levels and which partially overcomes the limitations of former analyses using geoprocessing 15,16.

\section{Methods}

\section{Data}

Data on the reporting of new AIDS cases among UDIs for each year between 1986 and 2000 were obtained from the Brazilian AIDS Cases Databank (SINAN-AIDS) for the period 1986-2000.

We classified cases as belonging to the "injection drug users" exposure category following the hierarchical classification approach proposed by The Joint United Nations Programme on HIV/AIDS (UNAIDS) 17. In this approach injection drug users are classified under this broad category, even if included in additional exposure categories (i.e., categories 11, 14, 15, 21, $24,25,31,34,35,40,41,42,61,64,65 \& 67$, as defined by SINAN-AIDS, Brazilian Ministry of
Health). We double-checked this information with the variable: "ever used injecting drugs [for non-therapeutic purposes]”, from SINAN-AIDS. We found an agreement of approximately $98 \%$ between the two definitions, and thus adopted the UNAIDS standard classification.

We calculated rates of new AIDS cases (where HIV infection was acquired through IDUs) for those Brazilian municipalities which had registered at least 15 AIDS cases in the 15-69-year age bracket during this period. This yielded 255 out of 5,507 Brazilian municipalities, from 23 States (of a total of 27 Brazilian States). Demographic data for each municipality were downloaded from the Departamento de Informações e Informática do SUS site (DATASUS: http: //www.datasus.gov.br). In order to standardize the effect of age structures in the different municipal populations, we calculated the directly standardized recording rate by age group (15$19,20-29,30-39,40-49,50-59$, and 60-69 years), using the Brazilian population for the year 2000 as the reference population.

A set of socioeconomic and structural indicators which might be associated with the variability of the standardized rates of AIDS cases among IDUs was constructed, using 1991 and 2000 census data, and from a comprehensive inter-census assessment of educational indicators carried out in 1996. This included: adult literacy rate; proportion of persons older than 15 years who had completed 8 years of schooling; proportion of residents with: (a) running water; (b) municipal garbage collection; and (c) sewerage, used as housing indicators. "Per capita income" and "the Gini coefficient" were used to assess income and income inequality. In relation to social vulnerability and health infrastructure, we used two indicators: the proportion of households headed by women with children younger than 15 years and the number of physicians per inhabitant. We used the Human Development Index (HDI) as a composite index that measures average achievement in three basic aspects of human development: longevity, knowledge, and standard of living (available at http://hdr.undp.org/). To describe population dispersion we used the proportion of the urban population for each municipality and the distance (in $\mathrm{km}$ ) from each municipality to the respective State capital, also explored in the analyses.

Indicators for schooling, water supply, sewerage, and garbage collection were downloaded from the above-mentioned DATASUS site. All other indicators were downloaded from the Brazilian site of the United Nations Development Program (PNUD-Brasil: http://www.pnud.org.br). 


\section{Analysis}

Because the data structure gives (a) multiple observations on single units of analysis and (b) natural geographically-determined hierarchy of observations (municipality / State), a multi-level model was used in order to take into account (a) correlation within units in AIDS incidence over time and (b) correlation of AIDS incidence between different municipalities and States. We considered time as the first level, corresponding to the 15-year period (1986-2000) under analysis, municipalities as the second level (255), and Brazilian States (23) as the third level.

Logged AIDS standardized incidence rates among IDUs were used as the outcome in order to provide a better approximation to the linear function and normal distribution. MlwiN (Multilevel Models Project Institute of Education) software, version 2.0, was used for all analyses.

In order to assess colinearity, a correlation matrix including all covariates was constructed.

The analyses were performed in two steps, starting with univariate analyses. The variables shown to be associated with the outcome, considering a significance level of $5 \%$, were included in the multivariate analysis. Covariates were then selected using a backward stepwise procedure, based on maximum likelihood ratio test. Residual analyses were carried out to evaluate the underlying assumptions of the multilevel model.

\section{Results}

Before presenting the results of the multilevel model, we briefly illustrate the distribution of AIDS cases for Brazil, 1980-2002. Figure 1 shows the distribution of AIDS cases according to exposure categories among the population older than 13 years.

As depicted in Figure 1, the proportion of IDUs among AIDS cases increased in the late 1980 s, reached a peak in the early 1990s, and declined thereafter, with a substantial increase of cases acquired through heterosexual transmission.

We also illustrate the spatial distribution of AIDS cases among IDUs across the different Brazilian regions, using the AIDS accumulated rates, for 1984-2000. In order to improve the representation, we smoothed the rates according to the Brazilian micro-regions, as defined by the Instituto Brasileiro de Geografia e Estatística (IBGE) (Figure 2).

As expected, "per capita income" and schooling indicators showed a strong correlation with HDI (data not shown), because the HDI contains these in its composition. Therefore, only the HDI was included in the intermediate models. The indicators related to sewerage, garbage collection, and the proportion of population living in urban areas did not explain variations in AIDS cases across municipalities in the univariate analyses and were excluded from further analyses.

Figure 1

AIDS incidence rate (per 100,000 inhabitants) by exposure categories among the population

older than 13 years. Brazil, 1982-2002.

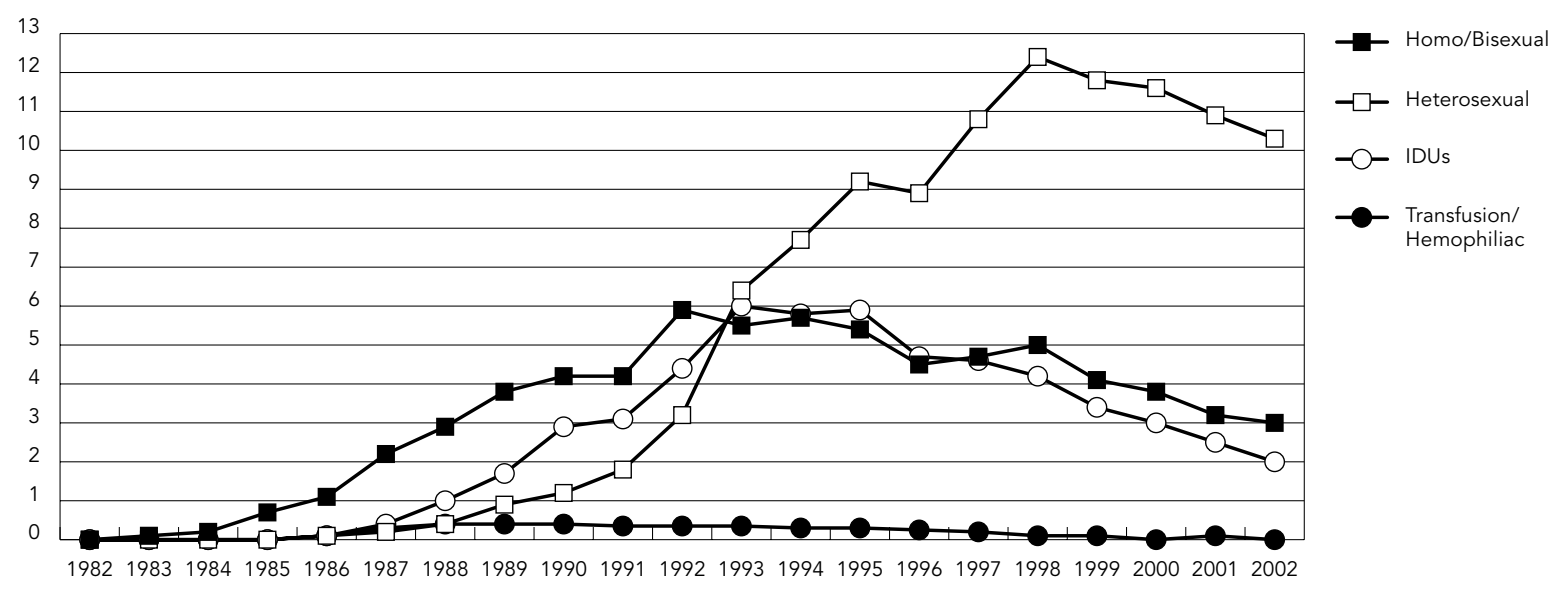




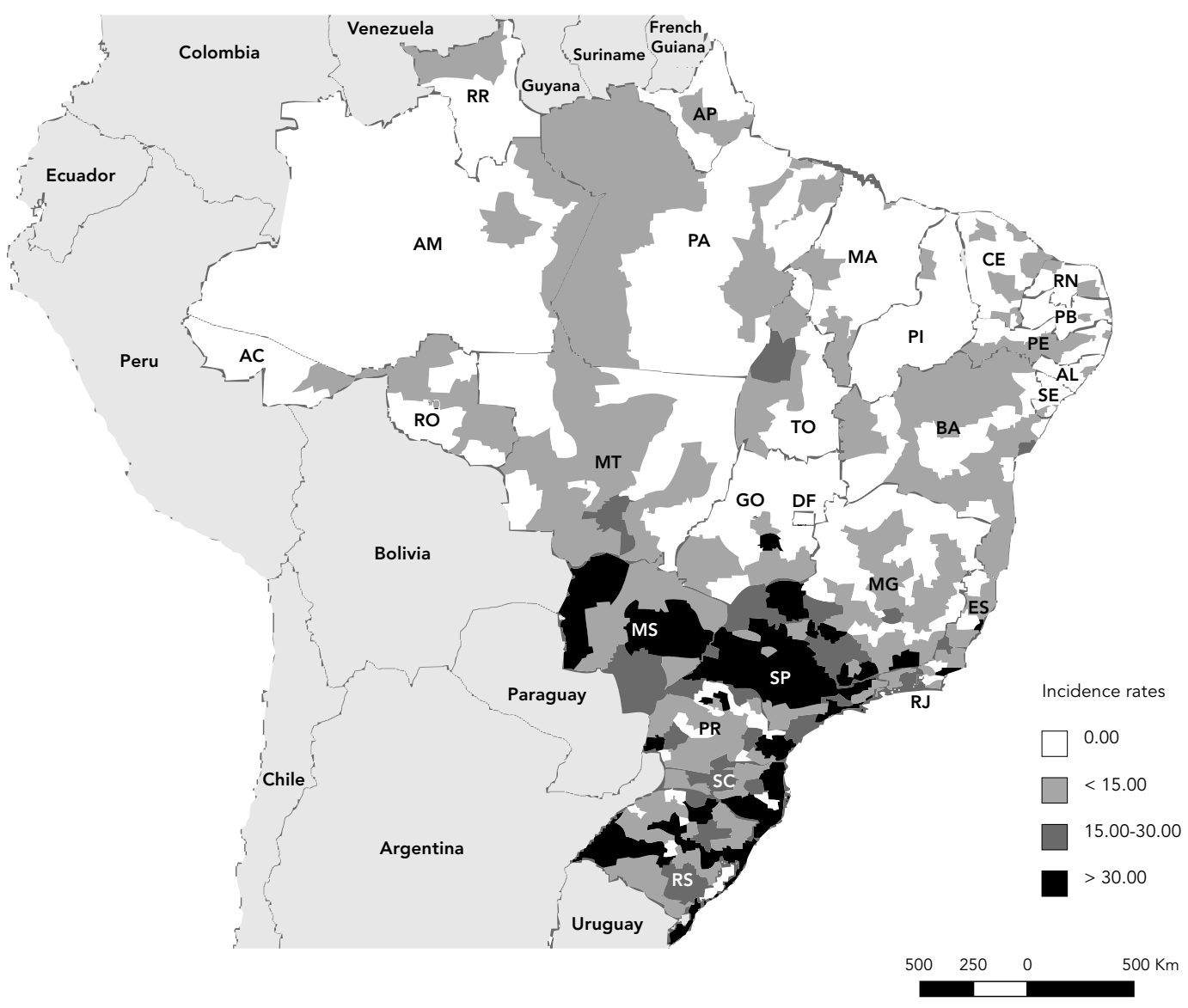

Source: SINAN/AIDS - MS

Electronic map: IBGE

Geoprocessing by: LABGEO/FIOCRUZ

Therefore, the final model is formed by an intercept (allowed to vary across the 3 levels: States, municipalities, years), a parameter describing the effect of the variable "time" (with random effects at the level of municipality and State ), a parameter referred to "time squared" (with random effects at the level of municipality and State), and by the variables "number of physicians per inhabitant" and "standard distance to the State capital" defined at the level of the municipality. The model coefficient estimates for the selected variables and their respective standard errors are presented in Table 1.

Figure 3 presents the predicted standardized rates, based on the estimated parameters, for each municipality and State. An average line was imposed on each graph, assuming no effect at the municipal level. States from the North and Northeast present the lowest rates and the smallest number of municipalities reporting AIDS cases among IDUs, basically restricted to their respective capitals or main metropolitan areas. In the Central West, rates were found to be higher, and in some States such as Goiás and Mato Grosso do Sul, AIDS cases were spread across different municipalities. States located in the South and Southeast especially (São Paulo and Santa Catarina) contained the municipalities with the highest rates. In these, AIDS cases among IDUs had been recorded in municipalities located across the entire State territory and were not confined to major urban concentrations. 
In some municipalities (including several from the States of Santa Catarina and Rio Grande do Sul, Brazil's southernmost states), the AIDS incidence rates appear to be increasing. In Santa Catarina, the most heavily affected municipalities are Laguna, Joinville, Blumenau, Jaraguá do Sul, and Lages. In Rio Grande do Sul, the incidence has been increasing in all municipalities, with the single exception of Porto Alegre (the State capital) and Passo Fundo, where the incidence rates appear to have stabilized.

To further explore the effect of the municipality's distance from the State capital, we conducted additional analyses. The distance between each municipality and the State capital (in $\mathrm{km}$ ) is plotted against the logged standardized AIDS incidence rate in Figure 4, with the States ordered from left to right and from top to bottom according to Brazilian regional geography.

In some States, especially in the North and Northeast, AIDS cases are located very near to the State capital or have been recorded exclusively in the capital. As mentioned above, such findings contrast with those for municipalities located in the Central West and especially with those located in the industrialized regions of the South and Southeast. Since approximately $74 \%$ of cases recorded among IDUs are located in the States of São Paulo (Southeast) and Rio Grande do Sul (South), the overall effect on the Brazilian epidemic in this population is strongly influenced by these States and their respective regions.

\section{Discussion}

Previous analyses conducted at different levels of aggregation have suggested an apparent paradox: while there is a strong concentration of AIDS cases among IDUs in the wealthiest and most industrialized areas of Brazil (the South and Southeast), the vast majority IDUs recorded as AIDS cases are from the poorest strata of Brazilian society 12 , one of the most unequal in the world 18. The present analysis offers additional insight, exploring the interplay of determinants situated at the meso and macro levels.

At its outset, the AIDS epidemic among Brazilian IDUs followed the main cocaine trafficking routes, from the West (bordering on coca/cocaine-producing areas) to the main ports located on the southeastern coast 15,16. Visual inspection shows a strip of high HIV incidence running from the Central West to the Southeast, crossing the wealthiest municipalities in
Table 1

Coefficient and confidence interval of variables in the final multilevel model.

\begin{tabular}{lcc}
\hline Fixed part & Coefficient & $95 \% \mathrm{Cl}$ \\
\hline Constant & -1.343 & $(-1.741 ;-0.945)$ \\
$\quad$ State & 0.533 & $(0.086 ; 0.980)$ \\
Municipality & 0.987 & $(0.644 ; 1.330)$ \\
Year & 0.318 & $(0.298 ; 0.338)$ \\
& & \\
Time & 0.452 & $(0.395 ; 0.509)$ \\
State & 0.003 & $(0.001 ; 0.005)$ \\
Municipality & 0.086 & $(0.061 ; 0.111)$ \\
& & \\
Time 2 & -0.022 & $(-0.024 ;-0.020)$ \\
Municipality & 0.001 & $(0.001 ; 0.001)$ \\
Distance to the State capital* & 0.001 & $(0.001 ; 0.002)$ \\
Number of physicians per inhabitant* & 0.076 & $(0.005 ; 0.147)$ \\
\hline
\end{tabular}

* indicators were centered at their respective mean values.

São Paulo, probably reflecting the better transportation networks and opportunities for traffickers to sell the cocaine en route to export points 15,16 .

In recent years, AIDS incidence among IDUs has stabilized or declined in the municipalities affected early by the epidemic. This may reflect saturation, spontaneous behavior change, or the effects of preventive programs. The effectiveness of the latter has been demonstrated by numerous studies among IDUs using different indicators and outcomes, such as HIV prevalence and incidence, risk behaviors, and prevalence of different blood-borne infections 19,20,21,22,23,24.

However, no such stabilization or decline has been observed in the South. Our findings show that current trends for the northernmost State of the South (Paraná) roughly follow the patterns described for São Paulo and the other Southeast States in the early years of the epidemic. Our findings also suggest that the epidemic has been spreading among IDUs from some municipalities of Santa Catarina and most municipalities of Rio Grande do Sul, Brazil's southernmost States. These States have been deeply affected by the epidemic since the mid1980 s, and in many municipalities the epidemic progressed unabated in the late 1990s.

Our findings for AIDS incidence (which reflect epidemics of HIV transmission occurring several years earlier) are also supported and extended by individual-level studies, documenting persistently high HIV infection rates in southern municipalities 25,26 . The main difference between our findings (based on AIDS 
Figure 3

Predicted AIDS incidence standardized rates, 1986-2000.
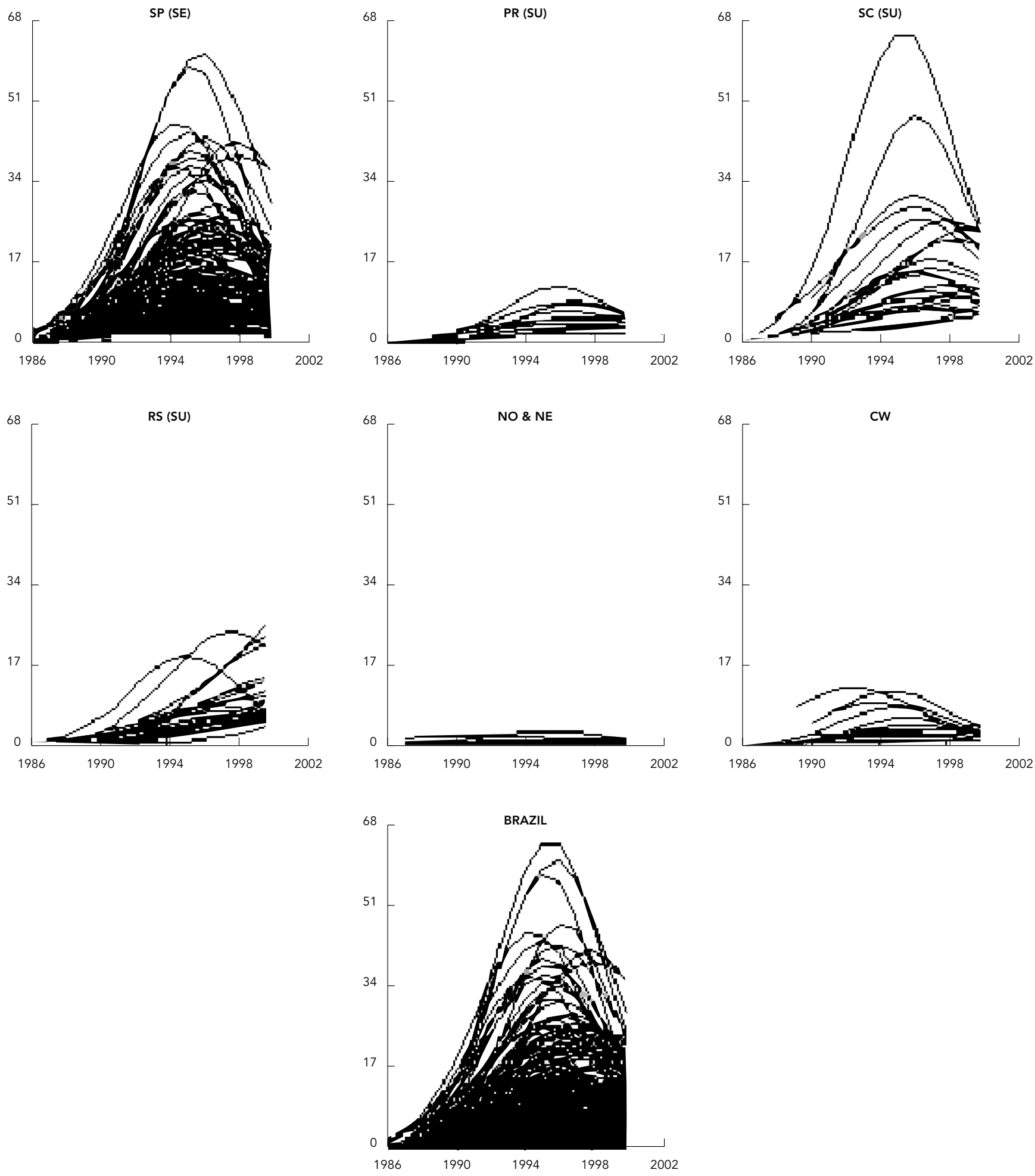

Footnotes: NO = North region; NE = Northeast region; CW = Central-West region; SE = Southeast region; SP = São Paulo State; $\mathrm{SU}=$ South region; $\mathrm{PR}=$ Paraná State; $\mathrm{SC}=$ Santa Catarina State; RS = Rio Grande do Sul State. 


\section{Figure 4}

Neperian logarithm of standardized rate versus standard distance to the State capital (km), 1986-2000.
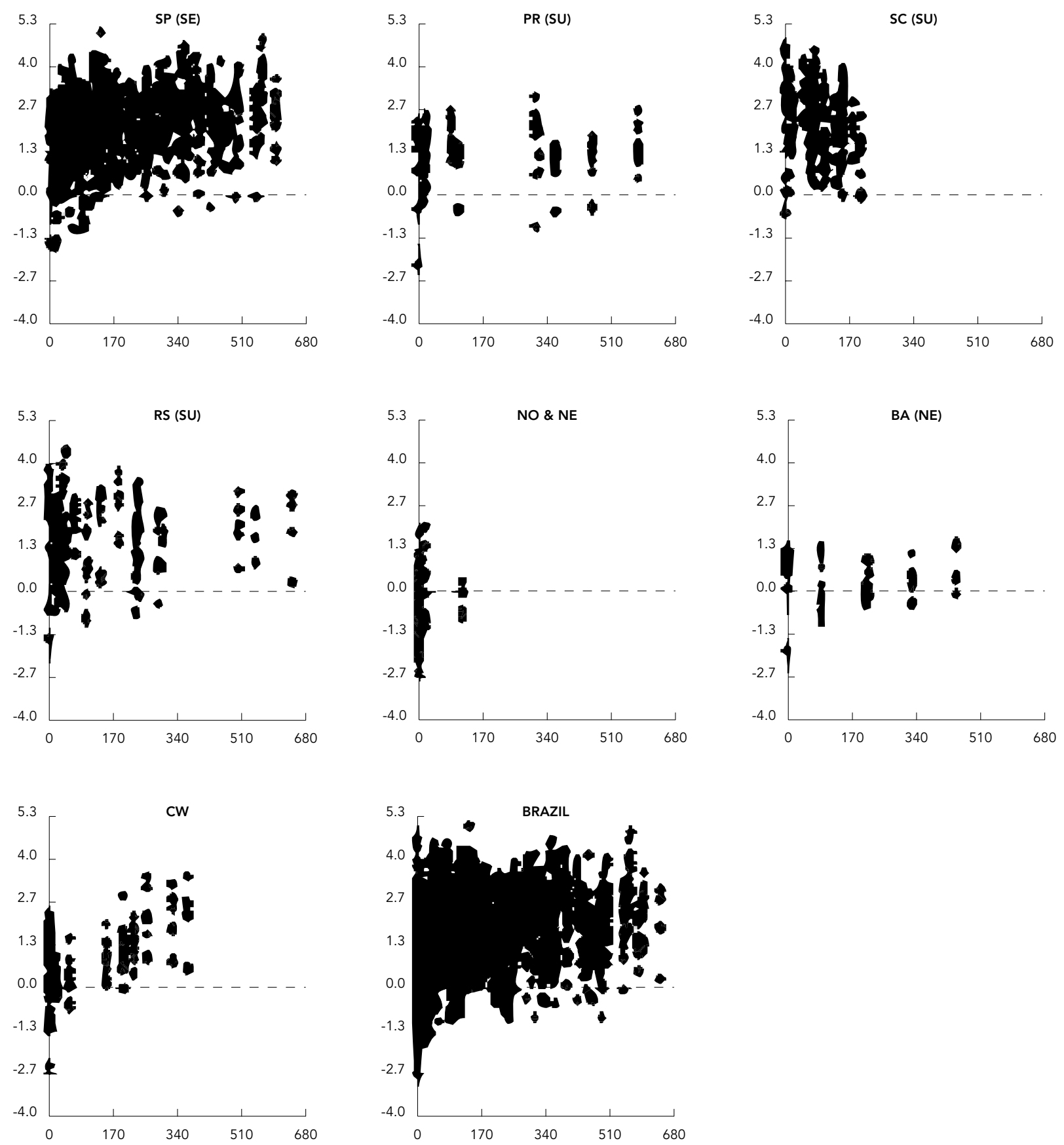

Footnotes: $\mathrm{NO}=$ North region; $\mathrm{NE}=$ Northeast region; $\mathrm{BA}=$ Bahia State; $\mathrm{CW}=$ Central-West region; $\mathrm{SE}=\mathrm{Southeast}$ region; $\mathrm{SP}=$ São Paulo State; SU = South region; PR = Paraná State; SC = Santa Catarina State; RS = Rio Grande do Sul State. 
data) and those from studies reporting HIV infection rates in the late 1990s through 2000 relates to Porto Alegre, the capital of Rio Grande do Sul. In Porto Alegre, our analyses suggest a decline in incidence, in contrast to the disquieting increase among IDUs, recruited in local communities in 1998 and 200026 and a high HIV incidence among non-injecting heavy cocaine users from a cohort followed from 1996 to 1998 25. However, both our findings and inferences are based on non-random samples of hard-to-reach populations and should thus be viewed with caution. Considering the noncommensurability of studies conducted at the individual and ecological levels, we may hypothesize that a new wave of HIV transmission took place in the late 1990s among IDUs from Porto Alegre, yet to be captured by AIDS surveillance.

In a country with deep social contrasts, we explored the relationship between a comprehensive set of social inequality indicators and the spread of AIDS among Brazilian IDUs. Since health services can also be important; and given the persistent geographic imbalance in the National Health System, we also used the number of physicians per inhabitant in our analysis. Such heterogeneities impose some limitations on the analyses conducted in the present paper.

Despite health policy efforts to universalize access to health care 27 , Brazil still maintains an unfair distribution of financial resources among regions, and delivery of health care services remains extremely unequal across the country 28. Physicians are still concentrated in the larger and better served urban centers.

AIDS cases among IDUs can thus tend to concentrate in wealthier and better equipped municipalities, where higher average incomes and concentrations of IDUs can foster the establishment of drug smuggling and consuming networks 29. This collective phenomenon can occur despite that fact that individual IDUs belong to dispossessed and marginalized strata 30 .

In several European countries, HIV prevalence among IDUs shows considerable variation between and within countries 9 . The late upsurge of drug consumption and AIDS cases among injection drug users in Portugal in the context of trends in other southern European countries 31 illustrates how wealthier and more developed societies may be affected by increased access to illicit drugs and to the harms associated with drug injection 32 . The complex interplay between globalization, social change, drug trafficking and consumption, and increasing social inequality is further dramatically il- lustrated by the rapid and extensive spread of HIV/AIDS among Eastern European IDUs 5,31,33.

We found that AIDS occurrence among IDUs is significantly and positively correlated with longer distances from metropolitan areas. This could be viewed as an apparent paradox, since in the vast majority of Brazilian States, AIDS cases in this population are restricted to the main metropolitan areas, if not to the State capitals themselves. However, additional analyses showed that specific and contrasting geographic patterns can be discerned in different States.

Whereas in some States of the North and Northeast the epidemic among IDUs could be accurately described as incipient, the São Paulo epidemic has reached an extensive network of large, middle-sized, and small municipalities, most of which located far from the capital. More recently (and on a smaller scale), similar epidemiological phenomena have been observed in the southern states.

It is difficult to provide conclusive explanations for the geographic variation in levels and trends in AIDS cases in Brazil. While our findings should be interpreted with caution, they do suggest the need for different policy and intervention responses. Targeting incipient epidemics will be the priority in some regions, while consolidating activities and promoting epidemic reversal will be the priority where mature epidemics have stabilized. Most challenging of all will be controlling epidemics that are far from being curbed, such as those prevailing in the South.

Brazilian regional heterogeneity in both differential under-reporting and report delay may have significantly biased our findings. Work published in Brazil has sought to address report delay and suggest ways to correct it 34 , and we have minimized this bias in our analyses by deliberately excluding the last four years of data. However, to the best of our knowledge no published paper has addressed differential under-reporting which is likely to result from the variable reliability of local and regional health information systems. We have thus not been able to mitigate bias from this source.

Triangulation of data from ecological and person-based analyses may provide Brazilian policymakers with important information to support the development of sound and culturally-sensitive interventions. Despite the usual limitations of secondary data, the major Brazilian databases provide an important resource for exploring epidemic trajectories at different levels of geographic aggregation, informing the tailoring of location-specific responses which should complement nationwide analysis. 


\section{Resumo}

A epidemia de HIVIAIDS entre usuários de drogas injetáveis (UDIs) apresenta, no Brasil, contrastes temporais e geográficos. Esta análise explora tais complexidades, com o emprego de modelagem multinivel. As taxas padronizadas de incidência de AIDS em UDIs para os municípios brasileiros (período 1986-2000) foram consideradas como variável-dependente, e um conjunto de indicadores sociais como covariáveis. Em alguns Estados do Norte e Nordeste, a epidemia é incipiente entre UDIs, enquanto a epidemia paulista atinge uma rede de municípios, a maioria deles distantes da capital. Mais recentemente, e em menor escala, disseminação análoga foi observada nos Estados mais meridionais. As covariáveis "número de médicos por habitante" $e$ "distância-padrão da capital do respectivo estado" se mostraram associadas à variáveldependente. Os casos de AIDS entre UDIs parecem se concentrar em municípios mais ricos e bem equipados. O peso relativo dessa disseminação extensa em Estados-chave, populosos, prevalece sobre o conjunto da epidemia brasileira, definindo uma faixa que se estende do Centro-oeste ao Sudeste, com municípios mais ricos, de médio porte, e, mais recentemente, uma faixa sul de municípios substancialmente afetados pela epidemia entre UDIs.

Uso Indevido de Drogas Parenterais; Síndrome de Imunodeficiência Adquirida; Distribuição Espacial; Incidência

\section{Contributors}

M. A. Hacker participated in the conceptualization, statistical analysis, and drafting of the manuscript. I. C. Leite contributed to the statistical analysis and review of the manuscript. A. Renton participated in the discussion and review of the manuscript. T. G. Torres participated in the statistical analysis. R. Gracie contributed to the data geoprocessing. F. I. Bastos participated in the conceptualization, discussion, and review of the manuscript.

\section{Acknowledgments}

The authors are grateful to the UK Department for International Development (DFID) who has financially supported this research as part of the program on Knowledge for Action in HIVIAIDS and STIs.

\section{References}

1. The Joint United Nations Programme on HIV/ AIDS/World Health Organization. AIDS epidemic update: December, 2004. http://www.unaids.org/ wad2004/EPI_1204_pdf_en/Chapter0-1_intro_ en.pdf (accessed on 15/Jan/2005).

2. Hu DJ, Subbarao S, Vanichseni S, Mock PA, van Griensven F, Nelson R, et al. Higher viral loads and other risk factors associated with HIV-1 seroconversion during a period of high incidence among injection drug users in Bangkok. J Acquir Immune Defic Syndr 2002; 30:240-7.

3. Hien NT, Giang LT, Binh PN, Wolffers I. The social context of HIV risk behaviour by drug injectors in Ho Chi Minh City, Vietnam. AIDS Care 2000; 12: 483-95.

4. Piyasirisilp S, McCutchan FE, Carr JK, SandersBuell E, Liu W, Chen J, et al. A recent outbreak of human immunodeficiency virus type 1 infection in southern China was initiated by two highly homogeneous, geographically separated strains, circulating recombinant form $\mathrm{AE}$ and a novel $\mathrm{BC}$ recombinant. J Virol 2000; 74:11286-95.

5. Rhodes T, Ball A, Stimson GV, Kobyshcha Y, Fitch C, Pokrovsky V, et al. HIV infection associated with drug injecting in the newly independent states, eastern Europe: the social and economic context of epidemics. Addiction 1999; 94:1323-36.

6. Rhodes T, Lowndes C, Judd A, Mikhailova LA, Sarang A, Rylkov A, et al. Explosive spread and high prevalence of HIV infection among injecting drug users in Togliatti City, Russia. AIDS 2002; 16:F25-31.

7. Des Jarlais DC, Hagan H, Friedman SR, Friedmann P, Goldberg D, Frischer M, et al. Maintaining low HIV seroprevalence in populations of injecting drug users. JAMA 1995; 274:1226-31.

8. Des Jarlais DC, Marmor M, Friedmann P, Titus S, Aviles E, Deren S, et al. HIV incidence among injection drug users in New York City, 1992-1997: evidence for a declining epidemic. Am J Public Health 2000; 90:352-9.

9. Hamers FF, Batter V, Downs AM, Alix J, Cazeins F, Brunet JB. The HIV epidemic associated with injecting drug use in Europe: geographic and time trends. AIDS 1997; 11:1365-74.

10. Rhodes T, Stimson GV, Crofts N, Ball A, Dehne K, Khodakevich L. Drug injecting, rapid HIV spread, and the 'risk environment': implications for assessment and response. AIDS 1999; 13:259-69.

11. Beyrer C, Razak MH, Lisam K, Chen J, Lui W, Yu XF. Overland heroin trafficking routes and HIV-1 spread in south and south-east Asia. AIDS 2000; 14:75-83.

12. Bastos FI, Strathdee SA. Evaluating effectiveness of syringe exchange programmes: current issues and future prospects. Soc Sci Med 2000; 51:1771-82.

13. Carrieri MP, Moatti JP, Vlahov D, Obadia Y, Reynaud-Maurupt C, Chesney M. Access to antiretroviral treatment among French HIV infected injection drug users: the influence of continued drug use. MANIF 2000 Study Group. J Epidemiol Community Health 1999; 53:4-8.

14. Prins M, Brettle RP, Robertson JR, Aguado IH, Broers NC, Goldberg DJ, et al. Geographical vari- 
ation in disease progression in HIV-1 seroconverted injecting drug users in Europe? Int J Epidemiol 1999; 28:547-9.

15. Barcellos C, Bastos FI. Redes sociais e difusão da AIDS no Brasil. Bol Oficina Sanit Panam 1996; 121:11-24.

16. Bastos FI, Pina MF, Szwarcwald CL. The social geography of HIV/AIDS among injection drug users in Brazil. Int J Drug Polic 2002; 13:137-44.

17. The Joint United Nations Programme on HIV/ AIDS. UNAIDS: 3rd meeting of the Latin America and Caribbean epidemiological network. Abstracts. Cuernavaca: The Joint United Nations Programme on HIV/AIDS; 1999.

18. World Bank. Brazil: inequality and economic development poverty assessment report. http://www. worldbank.org/data/countrydata/countrydata.ht $\mathrm{ml}$ (accessed on 18/Mar/2005).

19. Teixeira SLM, Bastos FI, Telles PR, Hacker MA, Brigido LF, Oliveira CAF, et al. HIV-1 infection among injection and ex-injection drug users from Rio de Janeiro, Brazil: prevalence, estimated incidence and genetic diversity. J Clin Virol 2004; 31: 221-6.

20. Hacker MA, Friedman SR, Telles PR, Teixeira SL, Bongertz V, Morgado MG, et al. The role of "longterm" and "new injectors" in a declining HIV/AIDS epidemic in Rio de Janeiro, Brazil. Subst Use Misuse 2005; 40:99-123.

21. Bastos FI, Bongertz V, Teixeira SL, Morgado MG, Hacker MA. Is human immunodeficiency virus/ acquired immunodeficiency syndrome decreasing among Brazilian injection drug users? Recent findings and how to interpret them. Men Inst Oswaldo Cruz 2005; 100:96-9.

22. Mesquita F, Kral A, Reingold A, Bueno R, Trigueiros D, Araujo PJ, et al. Trends of HIV infection among injection drug users in Brazil in the 1990s: the impact of changes in patterns of drug use. J Acquir Immune Defic Syndr 2001; 28:298-302.

23. Turchi MD, Diaz RS, Martelli CM, Sabino EC, Da Silva WP, Filho OF, et al. Genetic diversity and HIV-1 incidence estimation among cocaine users in Sao Paulo, Brazil. J Acquir Immune Defic Syndr 2002; 30:527-32.

24. Andrade T, Lurie P, Medina MG, Anderson K, Dourado I. The opening of South America's first Needle Exchange Program and an epidemic of crack use in Salvador, Bahia-Brazil. AIDS Behav 2001; 5:51-64.
25. Pechansky F, von Diemen L, Kessler F, Hirakata V, Metzger D, Woody GE. Preliminary estimates of human immunodeficiency virus prevalence and incidence among cocaine abusers of Porto Alegre, Brazil. J Urban Health 2003; 80:115-26.

26. Caiaffa WT, Proietti FA, Carneiro-Proietti AB, Mingoti SA, Doneda D, Gandolfi D, et al. The dynamics of the human immunodeficiency virus epidemics in the south of Brazil: increasing role of injection drug users. Clin Infect Dis 2003; 37 Suppl 5:S376-81.

27. Oliveira EX, Carvalho MS, Travassos C. Territórios do Sistema Único de Saúde: mapeamento das redes de atenção hospitalar. Cad Saúde Pública 2004; 20:386-402.

28. Almeida C, Travassos C, Porto S, Labra ME. Health sector reform in Brazil: a case study of inequity. Int J Health Serv 2000; 30:129-62.

29. Friedman SR, Aral S. Social networks, risk-potential networks, health, and disease. J Urban Health 2001; 78:411-8.

30. Flom PL, Friedman SR, Kottiri BJ, Neaigus A, Curtis R, Des Jarlais DC, et al. Stigmatized drug use, sexual partner concurrency, and other sex risk network and behavior characteristics of 18- to 24year-old youth in a high-risk neighborhood. Sex Transm Dis 2001; 28:598-607.

31. Hamers FF, Downs AM. The changing face of the HIV epidemic in Western Europe: what are the implications for public health policies? Lancet 2004; 364:83-94.

32. Houweling H, Wiessing LG, Hamers FF, Termorshuizen F, Gill ON, Sprenger MJ. An age-periodcohort analysis of 50,875 AIDS cases among injecting drug users in Europe. Int J Epidemiol 1999; 28:1141-8.

33. Aceijas C, Stimson GV, Hickman M, Rhodes T, on behalf of the United Nations Reference Group on HIV/AIDS Prevention and Care among IDU in Developing and Transitional Countries. Global overview of injecting drug use and HIV infection among injecting drug users. AIDS 2004; 18:2295303.

34. Barbosa MT, Struchiner CJ. The estimated magnitude of AIDS in Brazil: a delay correction applied to cases with lost dates. Cad Saúde Pública 2002; 18:279-85.

Submitted on 18/Mar/2005

Final version resubmitted on $16 / \mathrm{Sep} / 2005$ Approved on 26/Sep/2005 